Iryna Koval, Volodymyr Kislenko, Liliya Shevchuk and Volodymyr Starchevskyy

\title{
KINETIC REGULARITIES OF THE PROCESSES OF ACCUMULATION AN D DESTRUCTION OF MICROORGANISMS IN WATER AT BUBBLING OF THE DIFFERENT GASES
}

\author{
Lviv Politechnic National University, \\ 12, Bandera str., 79013 Lviv, Ukraine \\ izkoval@mail.ru
}

Received: February 09, 2011 / Revised: February 23, 2011 / Accepted: M ay 27, 2011

(C) Koval I., Kislenko V., Shevchuk L., Starchevskyy V., 2011

\begin{abstract}
Kinetics of microorganisms accumulation (the first stage) and destruction (the second stage) in water dispersion in the air atmosphere and at bubbling of oxygen, argon and helium has been investigated. The accumulation of microorganism takes place in oxygen and in the air atmosphere at the first stage. The microorganisms destruction was observed at bubbling of the system by argon, helium during the whole process, however, in the air atmosphere and oxygen - in the second stage. Mathematical model of these two processes was elaborated and the rate constants of microorganisms destruction and propagation were calculated.
\end{abstract}

Keywords: mathematical model, microorganisms, accumulation, destruction, gases.

\section{Introduction}

In our previous researches the influence of ultrasound (US) treatment and simultaneous action of the US and gases of different nature have been studied in the process of water disinfection [1-4]. It was found that the effectiveness of bactericidal action of the US depends on the nature of bubbling gases under sonication conditions. Thus, the efficiency of destruction of Sarcina bacteria type under the combination of US action ( $v_{\mathrm{US}}$ is $22 \mathrm{kHz}$, $\tau_{\mathrm{US}}$ is $2 \mathrm{~h}$ ) with the gases such as $\mathrm{Ar}, \mathrm{He}, \mathrm{CO}_{2}$ and $\mathrm{O}_{2}$ is 97; 95.3; 83.3 and $82.8 \%$, respectively [1]. The dependence of microbial destruction under the simultaneous Ar/US action depending on their initial concentration was investigated in [4].

The investigation of the water purification method under the US action of various microorganisms (MO) is marked by many positive results [5-10]. According to [11] the number of microorganisms $(N M)(105-150) \cdot 10^{3}$ cells $/ \mathrm{ml}$ of polluted water is increased in 20 times under the ultrasonic treatment $\left(v_{\mathrm{US}}=22 \mathrm{kHz}\right)$ in the argon atmosphere, while at bubbling of argon only - in 1.2-1.8 times under the same conditions. The bacteria destruction in the presence of argon alone with the effectiveness of water disinfection of 88-94\% was observed in [11].

However, the influence of gases alone on the MO viability in water is not still understood today. Therefore, several studies were conducted by us with the aim of the detailed consideration of this process that may be important for grounding and understanding the process of water disinfection at bubbling gases into water.

\section{Experimental}

Microbial dispersions were prepared by adding microbes of the specific type into the diaerated distilled water for researches of the process of the $N M$ change in the volume unit of water in the presence of different gases. The test-microorganisms were the spore formation Bacillus cereus bacteria type at the age of three days.

The microbial dispersion with $N M_{0}=10^{3}$ cells $/ \mathrm{cm}^{3}$ was maintained at the stable temperature $(T=303 \mathrm{~K})$ under stirring and without it. The gas exchange with atmospheric air of the microbial dispersion was provided under indicated conditions.

Oxygen, argon and helium were used as additional gases for the researches, which were bubbled into the microbial dispersion at the rate of $\sim 1 \mathrm{~cm}^{3} / \mathrm{s}$. The influence of gases on the motion of the process of the MO viability was studied at different concentration of the microbes: $N M_{01}=7 \cdot 10^{4}$ cells $/ \mathrm{cm}^{3}$ and $N M_{02}=11.57 \cdot 10^{4}$ cells $/ \mathrm{cm}^{3}-$ for argon; $N M_{01}=3.4 \cdot 10^{4}$ cells $/ \mathrm{cm}^{3}$ and $N M_{02}=4.8 \cdot 10^{4}$ cells $/ \mathrm{cm}^{3}$ - for helium. The influence of oxygen was investigated at high $\left(N M_{0}=7 \cdot 10^{4}\right.$ cells $\left./ \mathrm{cm}^{3}\right)$ and low 
$\left(N M_{01}=2.7 \cdot 10^{2}\right.$ cells $/ \mathrm{cm}^{3}$ and $N M_{02}=5 \cdot 10^{2}$ cells $\left./ \mathrm{cm}^{3}\right)$ concentrations of the MO. The duration of the process was $2 \mathrm{~h}$.

The volume of the investigated dispersion $\left(75 \mathrm{~cm}^{3}\right)$ in the glass reactor was cooled by water during the whole process. The temperature of the microbial dispersion was $288 \pm 1 \mathrm{~K}$.

The MO were grown in a Petri plate on the nutrient medium - meat and peptone agar in the thermostat TS$80 \mathrm{M}-3$ at $T=310 \mathrm{~K}$ for $48 \mathrm{~h}$. The sowings of samples of microbial dispersion $\left(1 \mathrm{~cm}^{3}\right)$ into a Petri plate were held by means of a deep method.

The dynamics of the change of microbial number in time was determined. The correlation coefficients and the rate constants of accumulation $\left(k_{g}\right)$ and destruction $\left(k_{d}\right)$ of Bacillus cereus bacteria type in the atmosphere of different gases were expected.

\section{Results and Discussion}

Investigation of the change of $N M$ in the volume unit of distilled water in time in the air atmosphere showed that it increases on the first stage and then decreases slowly (Fig. 1). The rate of MO growth (the first stage) is equal for the processes in a stationary regime and at a constant rotation of the dispersion. Obviously, the medium of $\mathrm{MO}$ growth contains nutrient substances and oxygen, which are needed for growth and accumulation of MO. The rate of the MO destruction (the second stage) is slower when the dispersion is being mixed. It can be connected with the aggregation and the sedimentation of MO or with the low rate of oxygen diffusion into the cells in the volume of microbial dispersion. At the same time when the dispersion of MO was aerated by argon and helium, the $N M$ decreases in the volume unit of the system from the beginning of the process (Figs. 2 and 3). The rate of the MO destruction was higher in the first case than in the second one. The shape of curves of the NM change in the volume unit of dispersion at bubbling of oxygen (Figs. 4 and 5) is similar to the curves in the air atmosphere (Fig. $1)$, but the rate of MO growth and destruction is larger (Table).

The rate of the MO destruction can be described by the kinetic reaction equation of the first order:

$$
-d N M / d t=k_{d} N M
$$

where $k_{d}$ is the rate constant of microorganism destruction, $\mathrm{s}^{-1} ; N M$ is the number of microorganisms in the volume unit of dispersion, cells $/ \mathrm{cm}^{3}$.

\section{Table}

The correlation coefficients $\left(\boldsymbol{R}_{d}^{2}, \boldsymbol{R}_{g}^{2}\right)$ and the rate constants of microorganism destruction $\left(\boldsymbol{k}_{d}\right)$ and accumulation $\left(\boldsymbol{k}_{g}\right)$

\begin{tabular}{|c|c|c|c|c|}
\hline Conditions & $R_{d}^{2}$ & $k_{\mathrm{d}}, \mathrm{s}^{-1}$ & $R_{g}^{2}$ & $k_{g}, \mathrm{~s}^{-1}$ \\
\hline In air atmosphere under mixing & 0.620 & $(2.7 \pm 0.4) \cdot 10^{-8}$ & 0.907 & $(9.25 \pm 0.08) \cdot 10^{-6}$ \\
\hline In air atmosphere without mixing & 0.899 & $(9.0 \pm 0.3) \cdot 10^{-8}$ & 0.907 & $(9.25 \pm 0.08) \cdot 10^{-6}$ \\
\hline $\mathrm{O}_{2}$ bubbling & 0.954 & $(1.07 \pm 0.05) \cdot 10^{-4}$ & 0.967 & $(9.76 \pm 0.06) \cdot 10^{-4}$ \\
\hline He bubbling & 0.937 & $(8.16 \pm 0.07) \cdot 10^{-5}$ & - & - \\
\hline Ar bubbling & 0.893 & $(2.3 \pm 0.1) \cdot 10^{-4}$ & - & - \\
\hline
\end{tabular}

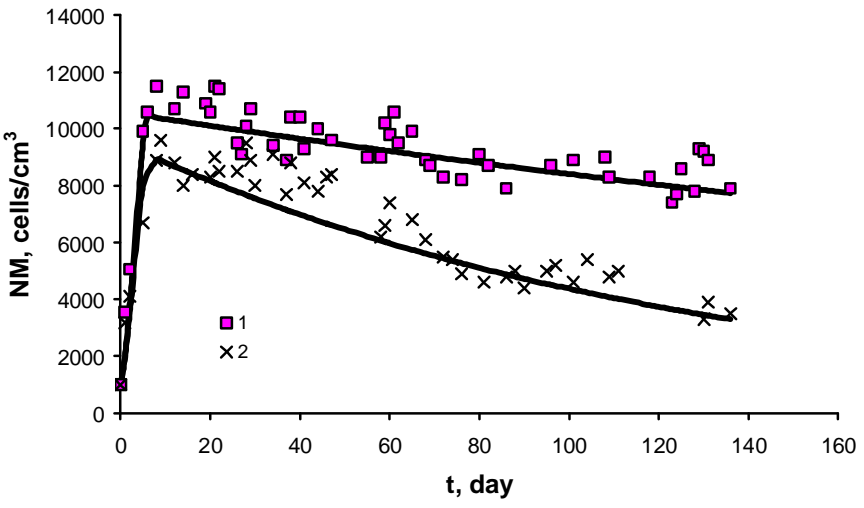

Fig. 1. Change of $N M$ in the volume unit of dispersion in air atmosphere at mixing of the system (1) and without mixing (2). Experimental data are described by the points. Theoretical curves are calculated according to the Eq. (13).

Conditions: $N M_{0}=10^{3}$ cells $/ \mathrm{cm}^{3} ; T=303 \mathrm{~K} ; P=0.1 \mathrm{MPa}$

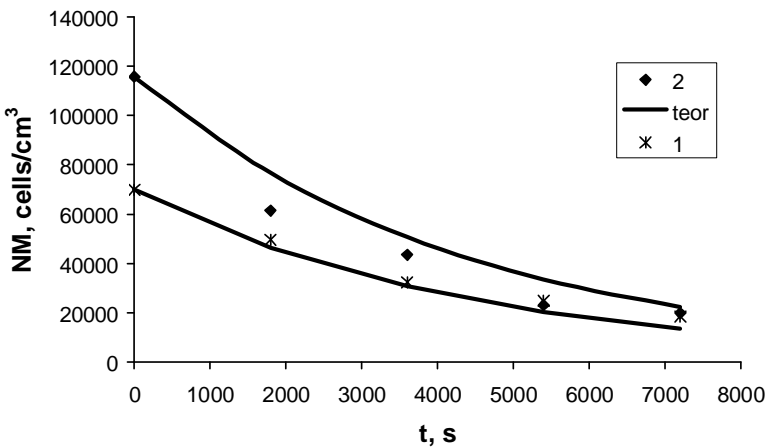

Fig. 2. Change of $N M$ in the volume unit of dispersion at bubbling of the system by argon at different $N M_{0}$. Experimental data are described by the points. Theoretical curves are calculated according to the Eq. (3). Conditions: $N M_{01}=7 \cdot 10^{4}$ cells $/ \mathrm{cm}^{3}$ (1); $N M_{02}=11.57 \cdot 10^{4}$ cells $/ \mathrm{cm}^{3}(2) ; T=288 \pm 1 \mathrm{~K} ; P=0.1 \mathrm{MPa}$ 


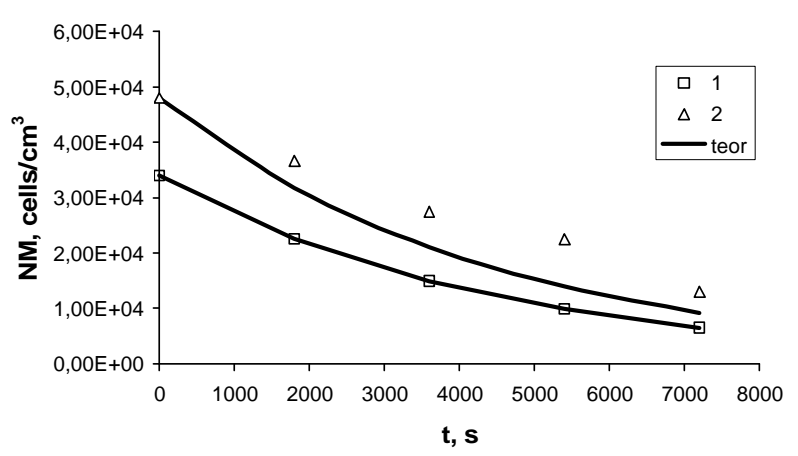

Fig. 3. Change of $N M$ in the volume unit of dispersion at bubbling of the system by helium at different $N M_{0}$. Experimental data are described by the points. Theoretical curves are calculated according

$$
\text { to the Eq. (3). Conditions: } N M_{01}=3.4 \cdot 10^{4} \text { cells } / \mathrm{cm}^{3}(1) \text {; }
$$$$
N M_{02}=4.8 \cdot 10^{4} \text { cells } / \mathrm{cm}^{3}(2) ; T=288 \pm 1 \mathrm{~K} ; P=0.1 \mathrm{MPa}
$$

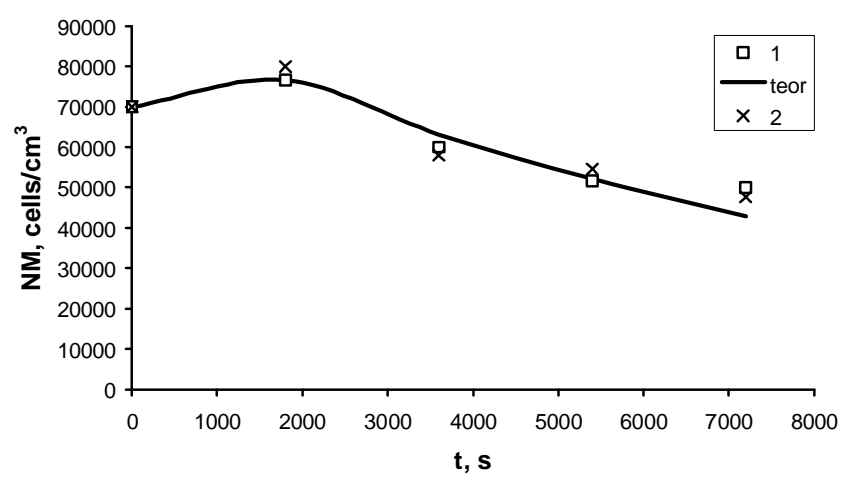

Fig. 5. Change of $N M$ in the volume unit of dispersion at the bubbling of the system by oxygen at the high $N M_{0}$. Experimental data are described by the points. Theoretical curves are calculated according to the Eq. (13). Conditions: $N M_{0}=7 \cdot 10^{4}$ cells $/ \mathrm{cm}^{3}(1,2)$; $T=288 \pm 1 \mathrm{~K} ; P=0.1 \mathrm{MPa}$

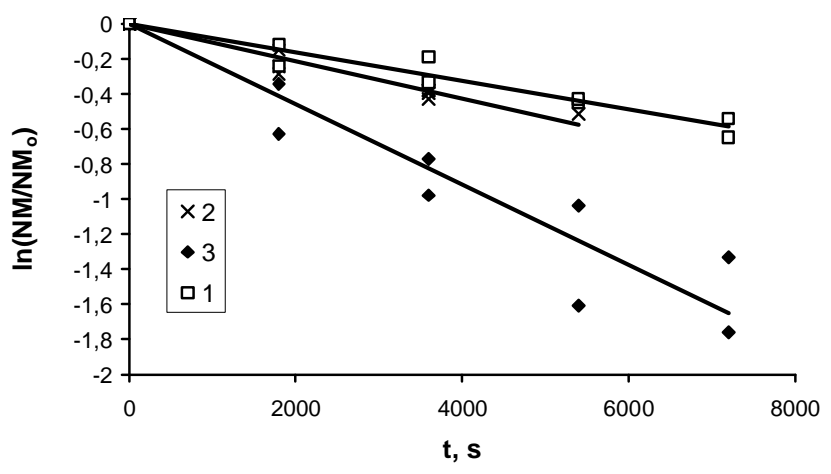

The experimental data of the decrease of the $N M$ in the volume unit of dispersion in the air atmosphere (Fig. 6 ) and at bubbling of the dispersion by oxygen, argon and helium (Fig. 7) are linear in coordinates of the Eq. (2) that is obtained by the integration of the Eq. (1).

$$
\ln \left(N M / N M_{0}\right)=-k_{d} t
$$

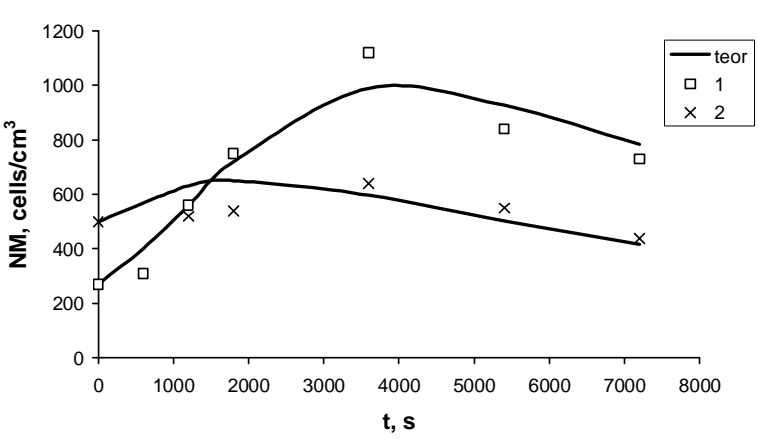

Fig. 4. Change of $N M$ in the volume unit of dispersion at bubbling of the system by oxygen at the low $N M_{0}$.

Experimental data are described by the points. Theoretical curves are calculated according to the Eq. (13).

Conditions: $N M_{01}=2.7 \cdot 10^{2}$ cells $/ \mathrm{cm}^{3}(1)$;

$N M_{02}=5 \cdot 10^{2}$ cells $/ \mathrm{cm}^{3}(2) ; T=288 \pm 1 \mathrm{~K} ; P=0.1 \mathrm{MPa}$

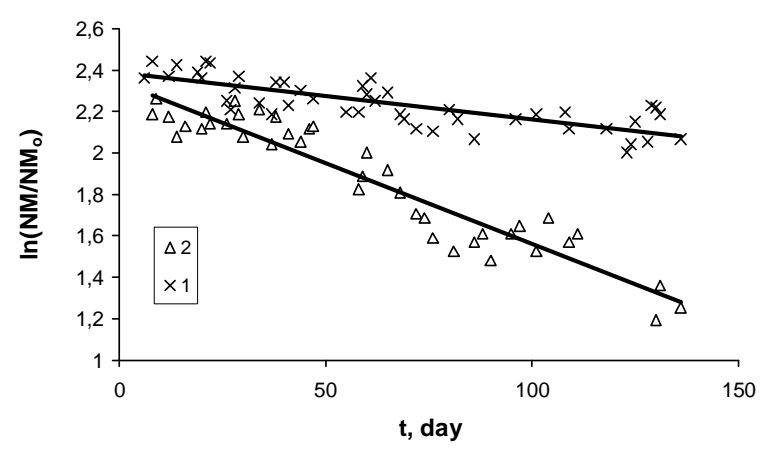

Fig. 6. Dependence of $N M$ in the volume unit of dispersion on time in coordinates of the Eq. (2) in the air atmosphere with mixing the system (1) and without mixing (2)

Fig. 7. Dependence of $N M$ in the volume unit of dispersion on time in coordinates of the Eq. (2) at bubbling of the system by helium (1), oxygen (2) and argon (3)

The correlation coefficients and the values of the rate constants are presented in the Table.

The change of the $N M$ in the volume unit of dispersion can be calculated according to the Eq. (3), that is obtained from the Eq. (2).

$$
N M=N M_{0} \exp \left(-k_{d} t\right)
$$


The theoretical curves (Figs. 2 and 3), calculated according to the Eq. (3), are described quit well by the experimental data of the $N M$ decrease in the volume unit of the dispersion at bubbling of the system by argon and helium.

The rate of the MO accumulation can be described by the equation:

$$
d N M / d t=k_{g} N M[S]
$$

where $k_{g}$ is the rate constant of the $N M$ increase in the volume unit of the dispersion; $[S]$ is the concentration of the nutrient substances in the medium.

The rate of the decrease of nutrient substances concentration in the medium can be described by the equation:

$$
-d[S] / d t=k_{n} N M[S]
$$

where $k_{n}$ is the rate constant of the nutrient substances spending.

The Eq. (6) can be obtained by division of the Eq. (4) by the Eq. (5)

$$
-d N M / d t=k_{g} / k_{n} d[S]
$$

The integration of the Eq. (6) at the initial conditions $N M=N M_{0},[S]=[S]_{0}$, where $N M_{0}$ is the initial $N M$ in the volume unit of the dispersion.

Denotation the initial concentration of nutrient substances in the system as $[S]_{0}$ leads to the Eq. (7):

$$
N M-N M_{0}=\frac{k_{g}}{k_{n}}\left([S]_{0}-[S]\right)
$$

The differential of the equation of $N M$ change in the volume unit of the dispersion can be obtained from the Eqs. (5) and (7):

$$
d N M / d t=k_{g} N M\left([S]_{0}-\frac{k_{n}}{k_{g}}\left(N M-N M_{0}\right)\right)
$$

The integration of the Eq. (8) at the initial conditions $t=0, N M=N M_{0}$ leads to the linear dependence of the $N M$ and the initial concentration of nutrient substances in time:

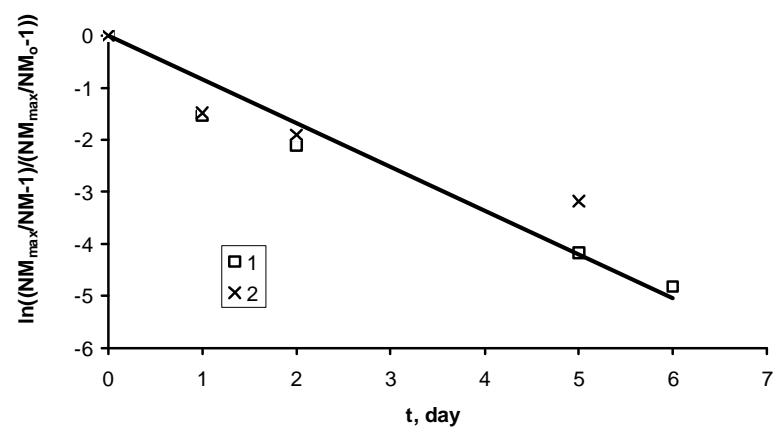

Fig. 8. Dependence of $N M$ in the volume unit of dispersion on time in coordinates of the Eq. (11) in the air atmosphere with mixing the system (1) and without mixing (2)

$$
\begin{aligned}
& \ln \left(N M_{0}\left(\frac{k_{g}}{k_{n}}[S]_{0}+N M_{0}-N M\right) /\left(N M \frac{k_{g}}{k_{n}}[S]_{0}\right)\right)= \\
& =-\left(k_{g}[S]_{0}+k_{n} N M_{0}\right) t
\end{aligned}
$$

At the first approximation the concentration of the nutrient substances in the system equals to zero at maximum of the $N M$ in the volume unit of the dispersion on the kinetic curve. Therefore the Eq. (7) can be transformed into the Eq. (10):

$$
[S]_{0}=\frac{k_{n}}{k_{g}}\left(N M_{\text {max }}-N M_{0}\right)
$$

where $N M_{\max }$ is the maximum number of microorganisms on the kinetic curve in the air atmosphere or at bubbling of the system by oxygen.

The Eq. (11) can be obtained using the Eqs. (9) and (10):

$$
\ln \left(\left(\frac{N M_{\max }}{N M}-1\right) /\left(\frac{N M_{\text {max }}}{N M_{0}}-1\right)\right)=-k_{n} N M_{\max } t
$$

Figs. 8 and 9 show that experimental data on the MO propagation in the air atmosphere and at bubbling of the system by oxygen are described quit well by the straight line in the coordinates of the Eq. (11). The correlation coefficients and the rate constants are presented in the Table.

The Eq. (10) can be transformed into the equation:

$$
N M=\frac{N M_{\text {max }}}{1+\left(\frac{N M_{\text {max }}}{N M_{0}}-1\right) \exp \left(-k_{n} N M_{\text {max }} t\right)}
$$

The change of the $N M$ in the volume unit of the dispersion in the air atmosphere and at bubbling of the system by oxygen can be obtained by summarizing the Eqs. (11) and (12).

$$
N M=\frac{N M_{\max } \exp \left(-k_{d} t\right)}{1+\left(\frac{N M_{\text {max }}}{N M_{0}}-1\right) \exp \left(-k_{n} N M_{\text {max }} t\right)}
$$

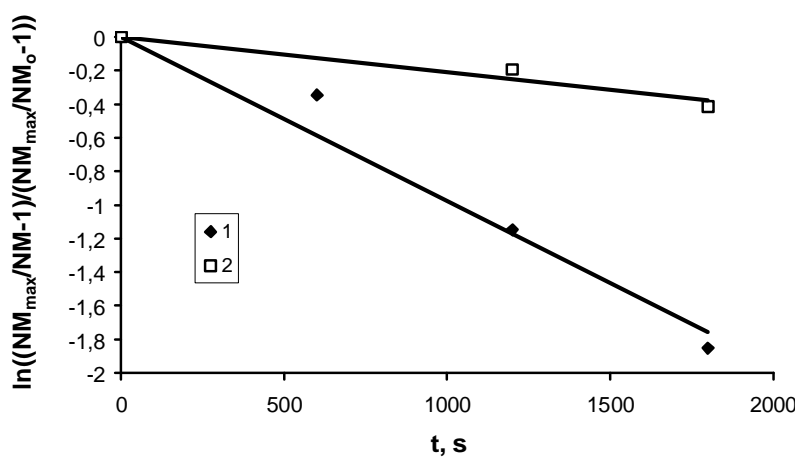

Fig. 9. Dependence of $N M$ in the volume unit of dispersion on time in coordinates of the Eq. (11) at bubbling of the system by oxygen at different $N M_{0}$ in the volume unit of the system. Conditions: 270 cells $/ \mathrm{cm}^{3}$ (1) and at 500 cells $/ \mathrm{cm}^{3}$ (2) 
Theoretical curves (Figs. 1 and 4-5), calculated according to the Eq. (13), are described quite well by the experimental data on the change of the $N M$ in the volume unit of the dispersion in the air atmosphere (Fig. 1) and at bubbling of the system by oxygen (Figs. 4 and 5).

Table shows that the rate constants of the MO accumulation are larger in the air atmosphere and oxygen in comparison with their destruction under same conditions and also shows that the rate constants of the MO destruction at bubbling of the system by oxygen, argon and helium are larger than in the air atmosphere.

\section{Conclusions}

Mathematical model, proposed by us, allows to describe the processes of accumulation and destruction of microorganisms in water in the presence of gases of different nature. It was determined that the processes of $N M$ increases at the first stage under the air and oxygen atmosphere conditions the processes of MO destruction at bubbling of all investigated gases (atmospheric air, oxygen, argon and helium) are described by the kinetic reactions equations of the first order.

\section{References}

[1] Starchevskyy V., Koval I., Shevchuk L. et al.: $11^{\text {th }}$ Meeting of the Eur. Soc. of Sonochemistry. France, La Grande-Motte 2008, 159.

[2] Koval I., Shevchuk L. and Starchevskyy V.: Voprosy Khim. i Khim. Techn., 2009, 6,133.

[3] Koval I., Shevchuk L. and Starchevskyy V.: Conf. GAS-2009. Ukraine, Lviv 2009, 69.
[4] Koval I., Starchevskyy V. and Shevchuk L.: $12^{\text {th }}$ Meeting of the Eur. Soc. of Sonochemistry. Greece, Chania, Crete 2010, 106.

[5] Mason T., Joyce E., Phull S. and Lorimer J.: Ultrason. Sonochem., 2003, 10, 319.

[6] Zhang G., Zhang P., Wang B. and Liu H.: Ultrason. Sonochem., 2006, 13, 446.

[7] Stamper D., Holm E. and Brizzolara R.: J. Environ. Eng. Sci., 2008, 7, 139.

[8] Dehghani M.: J. Environ. Sci., 2005, 1, 187.

[9] Loske A., Alvarez U., Hernandez-Galicia C. et al.: Innovat. Food Sci. Emerging Techn., 2002, 3, 321.

[10] Phull S., Newman A., Lorimer J. et al.: Ultrason. Sonochem., 1997, 4, 157.

[11] Shevchuk L., Starchevskyy V. and Kuzio O.: Visnuk NU "Lvivs'ka Polytechnika", 2005, 536, 178.

\section{КІНЕТИЧНІ ЗАКОНОМІРНОСТІ ПРОЦЕСІВ НАГРОМАДЖЕННЯ І РУЙНУВАННЯ МІКРООРГАНІЗМІВ У ВОДІ ПРИ БАРБОТУВАННІ РІЗНИХ ГАЗІВ}

Анотація. Досліджено кінетику нагромадження (I стадія) $i$ руйнування мікроорганізмів (II стадія) y водній дисперсії в атмосфері повітря і при барботуванні кисню, аргону і гелію. Нагромадження мікрооранізмів при барботуванні системи киснем $і$ в атмосфері повітря відбувається на пермій стадіï. Загибель мікроорганізмів спостерігалась при барботуванні аргоном, гелієм протягом всього прочесу, однак в атмосфері повітря та кисню - на другій стадї. Розроблена математична модель обох прочесів та обчислені константи швидкості нагромадження і руйнування мікроорганізмів.

Ключові слова: математична модель, мікроорганізми, нагромадження, руйнування, газ. 